\title{
Effect of diethylstilbestrol on cell proliferation and expression of epidermal growth factor in the developing female rat reproductive tract
}

\author{
A Okada ${ }^{1,2}$, T Sato $^{3}$, Y Ohta ${ }^{2,5}$, D L Buchanan ${ }^{4,5}$ and T Iguchi ${ }^{4,5}$ \\ ${ }^{1}$ Safety Research Laboratories, Yamanouchi Pharmaceutical Co., Ltd, Itabashi, Tokyo 174-8511, Japan \\ ${ }^{2}$ Laboratory of Animal Science, Department of Veterinary Science, Faculty of Agriculture, Tottori University, Tottori 680-8553, Japan \\ ${ }^{3}$ Graduate School of Integrated Science, Yokohama City University, Yokohama, Kanagawa 236-0027, Japan \\ ${ }^{4}$ Center for Integrative Bioscience, Okazaki National Research Institutes, Okazaki, Aichi 444-8585, Japan \\ ${ }^{5}$ CREST, Japan Science and Technology Corporation, Kawaguchi, Saitama 332-0012, Japan \\ (Requests for offprints should be addressed to T Iguchi, 38 Nishigonaka, Myodaiji, Okazaki, Aichi 444-8585, Japan; Email: taisen@nibb.ac.jp)
}

\begin{abstract}
To evaluate mechanisms of cell proliferation in the fetal female rat reproductive tract, diethylstilbestrol (DES) effects on cell division and estrogen receptor (ER), epidermal growth factor (EGF) and EGF receptor (EGF-R) expressions were determined from gestational day (GD) $15 \cdot 5$ to $21 \cdot 5$. Reproductive tracts were evaluated within three regions along the Müllerian duct axis; these were proximal, middle and caudal, which differentiate into oviduct, uterus and upper vagina respectively. In fetuses from non-treated dams, epithelial and mesenchymal proliferation, as evaluated by 5-bromo-2'-deoxyuridine incorporation, was decreased with development in all regions of the Müllerian duct. EGF levels were determined by immunohistochemistry. Müllerian epithelial EGF immunoreactivity was intense in the proximal and middle regions on GDs $15 \cdot 5$ and 17.5. EGF staining remained intense only in the proximal epithelia by GD 19.5 and was weak in the caudal epithelium, but substantially reduced throughout epithelia in all regions by GD
\end{abstract}

21.5. Thus, decreased cell proliferation correlated with decreased EGF expression in the developing Müllerian duct. DES $(100 \mu \mathrm{g} / \mathrm{kg}$ body weight $)$ was injected from GD 15 to 19 and female fetuses were collected on GD 19.5. DES increased Müllerian duct cell proliferation in the proximal epithelium and mesenchyme but decreased it in the caudal epithelium compared with oil-treated controls. No proliferative DES effect was observed in any cell type in the middle region. Müllerian duct EGF immunoreactivity was suppressed by DES compared with oil. Competitive RT-PCR indicated DES also decreased mRNAs for EGF, ER $\beta 1$ and ER $\beta 2$, but not $E R \alpha$ and EGF-R. These results indicate EGF may be an important regulatory factor of Müllerian duct cell proliferation, and that DES may alter cell proliferation by disrupting normal EGF, ER $\beta 1$ and ER $\beta 2$ expression in the developing female rat reproductive tract.

Journal of Endocrinology (2001) 170, 539-554

\section{Introduction}

In mammals, male reproductive organs such as epididymis, vas deferens and seminal vesicles arise from the mesonephric or Wolffian duct, and female reproductive organs such as oviduct, uterus and upper vagina arise from the paramesonephric or Müllerian duct. After gonadal differentiation, androgens produced by Leydig cells induce Wolffian duct development, and Müllerian inhibiting substance (MIS) produced by Sertoli cells induces Müllerian duct degeneration in male fetuses. In female fetuses, Müllerian duct development and Wolffian duct degeneration occur due to a lack of androgens and MIS after gonadal differentiation (Josso \& Picard 1986). The pattern of cell proliferation in the female reproductive tract has been demonstrated in immature and adult rodents (McCormack \& Glasser 1980, Quarmby \& Korach 1984, Li 1994). However, such patterns in prenatal rodents are not well understood. Similarly, $17 \beta$-estradiol effects on reproductive tract cell proliferation have been well reported in immature and adult rodents (McCormack \& Glasser 1980, Quarmby \& Korach 1984). However, $\alpha$-fetoprotein limits fetal $17 \beta$-estradiol exposure in utero. Diethylstilbestrol (DES), a non-steroidal synthetic estrogen, is known to have high affinity for estrogen receptors (ERs), but not $\alpha$-fetoprotein (Raynaud et al. 1971, Raynaud 1973). Therefore, DES is a powerful tool for understanding the mechanisms of estrogen action in fetal rodents. Prenatal exposure to DES causes a variety of abnormalities in reproductive tracts including oviduct 
uncoiling, hyperplasia and adenocarcinoma of uterus and vagina in aged mice and rats (reviewed by Herbst \& Bern 1981), but the influence of DES exposure on Müllerian duct development during gestation has not been investigated in rats.

Two subtypes of ERs have been identified in rats: the classical receptor, ER $\alpha$ (Koike et al. 1987) and a novel receptor, ER $\beta$ (Kuiper et al. 1996). Recently, a new isoform of $E R \beta$ named $E R \beta 2$ was cloned in rats, and the original ER $\beta$ was renamed ER $\beta 1$. ER $\beta 2$ has an additional $54 \mathrm{bp}$ sequence in the ligand-binding domain and is expressed in various rat tissues (Maruyama et al. 1998, Petersen et al. 1998). Although physiological roles of the $\operatorname{ER} \beta$ isoforms are unknown, they are thought to regulate estrogen action since both have different binding affinities for ligands including $17 \beta$-estradiol (Petersen et al. 1998). $\mathrm{ER} \alpha$ binding affinity for DES is slightly greater than that of ER $\beta 1$ and ER $\beta 2$, but in all cases affinity for DES is much greater than that for $17 \beta$-estradiol (Kuiper et al. 1997, Petersen et al. 1998). Since ER $\alpha$ is expressed in the fetal mouse Müllerian duct (Greco et al. 1991), prenatally administered DES may act through ER $\alpha$ and cause functional reproductive tract abnormalities in the female. ER $\beta$ expression has not been reported in the Müllerian duct. Altered c-jun, c-fos, epidermal growth factor (EGF) receptor (EGF-R) and ER $\alpha$ levels were observed in adult mouse reproductive tract exposed neonatally to DES (Iguchi et al. 1993, Kamiya et al. 1996, Sato et al. 1996), suggesting that DES may induce reproductive abnormalities by changing the normal expression levels of growth factors, their receptors and/or proto-oncogenes. To understand the effect of DES on Müllerian duct function and clarify the mechanism of cell proliferation, we subdivided the Müllerian duct into three main regions (proximal, middle and caudal) along the cranial-caudal axis and examined cell proliferation and ontogenetic expression of EGF within the defined regions during development. Prenatal effects of DES on EGF, EGF-R, ER $\alpha, E R \beta 1$ and ER $\beta 2$ mRNA expression were also determined.

\section{Materials and Methods}

\section{Animals and DES treatments}

Male and female Sprague-Dawley rats were obtained from Charles River Japan, Inc. (Kanagawa, Japan). Animals were housed individually in stainless-steel cages with controlled temperature $\left(23 \pm 2{ }^{\circ} \mathrm{C}\right)$ and relative humidity $(55 \pm 10 \%)$, and a $13 \mathrm{~h}$ light: $11 \mathrm{~h}$ darkness cycle $(0800$ 2100 h). Pellet food (CRF-1; Oriental Yeast Co., Ltd, Tokyo, Japan) and municipal tap water were freely available. Females were cohabited overnight with males. The day on which sperm was found in a vaginal smear was designated as gestational day (GD) 0. All animals were maintained in accordance with the institutional guidelines for care and use of laboratory animals.
To investigate DES effects on cell proliferation and expression of EGF, EGF-R, ER $\alpha, E R \beta 1$ and ER $\beta 2$, pregnant rats were given a single s.c. injection of DES (Sigma Chemical Co., St Louis, MO, USA) dissolved in peanut oil, or oil vehicle alone, on each day beginning on GD 15 through to 19 at a dose of $100 \mu \mathrm{g} / \mathrm{kg}$ body weight. To monitor the extent of cell proliferation, pregnant rats were injected (i.p.) $5 \mathrm{~h}$ prior to killing with $100 \mathrm{mg} / \mathrm{kg}$ 5-bromo-2'-deoxyuridine (BrdU) (Sigma).

\section{Tissue preparation}

Pregnant rats were killed by exsanguination from the abdominal aorta under ether anesthesia on GD $15 \cdot 5,17 \cdot 5$, 19.5 and 21.5 for normal development and control studies and on GD 19.5 for DES studies. Fetuses were removed and fixed with $4 \%$ paraformaldehyde in $0.1 \mathrm{M}$ phosphate buffer overnight at $4{ }^{\circ} \mathrm{C}$, then dehydrated through a graded series of ethanol concentrations and xylene. Tissues were then paraffin embedded and sectioned to $6 \mu \mathrm{m}$.

Cell proliferation was studied at three designated regions along the axis of the Müllerian duct as per Visser et al. (1998). The proximal region is identified at the level of the fetal ovary and is the region that differentiates into oviduct. The uterus arises from the middle region where the Müllerian and Wolffian ducts cross. The caudal region is near the urogenital sinus and differentiates into the upper part of the vagina.

\section{Immunohistochemistry for BrdU}

Tissue sections were deparaffined with xylene and hydrated in decreasing ethanol concentrations, rinsed three times in distilled water (DW) and incubated with $0 \cdot 1 \%$ trypsin (Sigma) in $0 \cdot 1 \% \mathrm{CaCl}_{2}$ for $30 \mathrm{~min}$ at $37^{\circ} \mathrm{C}$. After washing in DW, sections were incubated with $0 \cdot 3 \% \mathrm{H}_{2} \mathrm{O}_{2}$ in methanol for $30 \mathrm{~min}$ at room temperature (RT) to block endogenous peroxidases. After rinsing in $10 \mathrm{mM}$ PBS, pH.7·2, sections were incubated with monoclonal anti-BrdU antibody (Cell Proliferation kit; Amersham Pharmacia Biotech, Amersham, Bucks, UK) or PBS for 60 min at RT. Sections were then rinsed in PBS and treated with peroxidase anti-mouse IgG2a (Cell Proliferation kit; Amersham Pharmacia Biotech) for $30 \mathrm{~min}$ at RT. Sections were again rinsed in PBS and incubated with 3,3'-diaminobenzidine tetrahydrochloride (DAB) solution (Cell Proliferation kit; Amersham Pharmacia Biotech) for $10 \mathrm{~min}$ at RT. Finally, sections were counterstained with Mayer's hematoxylin. Cell proliferation was calculated as a percentage of the total BrdU-labeled cells counted; all epithelial cells in each section evaluated were counted. For mesenchymal stroma, all cells in the five layers most adjacent to the epithelium in each section were counted. 


\section{Immunohistochemistry for EGF and ERa}

For ER $\alpha$ immunohistochemical staining, deparaffined and rehydrated sections were autoclaved at $121{ }^{\circ} \mathrm{C}$ for $15 \mathrm{~min}$ in $10 \mathrm{mM}$ citrate buffer, at $\mathrm{pH} 6 \cdot 0$. Sections were subsequently rinsed in DW three times and incubated with $0 \cdot 3 \% \mathrm{H}_{2} \mathrm{O}_{2}$ in methanol for $30 \mathrm{~min}$ at $\mathrm{RT}$ to block endogenous peroxidases. After rinsing in PBS, 10\% normal goat serum blocking solution (Zymed Laboratories, Inc., San Francisco, CA, USA) was applied for $30 \mathrm{~min}$ at RT. Sections were incubated overnight at $4{ }^{\circ} \mathrm{C}$ with polyclonal anti-rat EGF antibody (IgG Co., Nashville, TN, USA) at a dilution of $1: 50$ or normal rabbit immunoglobulin fraction (DAKO A/S, Glostrup, Denmark) for EGF staining. For ER $\alpha$ staining, monoclonal anti-human ER $\alpha$ antibody (NCL-ER-6F11; Novocastra Laboratories, Ltd, Newcastle upon Tyne, UK) at a dilution of 1:50 or normal mouse IgG1 (DAKO A/S) in 10\% normal goat serum blocking solution was used. Following incubation, sections were rinsed in PBS and treated with biotinylated goat anti-mouse IgG (DAKO LSAB Kit; DAKO Corporation, Carpinteria, CA, USA) for $1 \mathrm{~h}$ at RT. Tissue sections were again rinsed in PBS and incubated with streptavidinconjugated horseradish peroxidase (DAKO LSAB Kit) for $1 \mathrm{~h}$ at RT. After a final PBS wash, sections were treated with $0 \cdot 01 \%$ DAB (Dojindo Laboratories, Kumamoto, Japan) in 0.05 M Tris- $\mathrm{HCl}$, at $\mathrm{pH} 7.6$ including 0.068\% imidazole (Sigma) and $0 \cdot 02 \% \mathrm{H}_{2} \mathrm{O}_{2}$ for $10 \mathrm{~min}$ at RT. For the evaluation of binding specificity of polyclonal antiEGF and monoclonal anti-ER $\alpha$ antibodies to rat tissues, submandibular glands isolated from adult male rats, or uterus and ovary isolated from adult female rats were immunostained with anti-EGF or anti-ER $\alpha$ antibodies respectively as positive controls. Tissues were also incubated with normal rabbit immunoglobulin fraction or anti-EGF antibody pre-absorbed with $50 \mathrm{ng}$ EGF peptide (Sigma) overnight at $4{ }^{\circ} \mathrm{C}$, or normal mouse IgG1 as negative controls.

\section{Total RNA preparation and competitive RT-PCR}

To collect fetal tissues, three pregnant rats were killed by exsanguination from the abdominal aorta under ether anesthesia on GD $15 \cdot 5,17 \cdot 5,19 \cdot 5$ and 21.5 . The female fetal reproductive tract was collected into ice-chilled diethylpyrocarbonate-treated PBS, and the gonad was dissected away under a dissecting microscope. Reproductive tracts were pooled from approximately 20 female fetuses per gestational day. Tissues were homogenized through a $23 \mathrm{G}$ sterile needle in Trizol (Gibco-BRL, Gland Island, NY, USA), and total RNA was isolated according to the manufacture's instructions. Total RNA concentration was assessed by $\mathrm{A}_{260}$ and RNA was stored at $-80{ }^{\circ} \mathrm{C}$ until needed.

Template total RNA $(1 \mu \mathrm{g})$ was reverse-transcribed by using SuperScript II RNase $\mathrm{H}^{-}$reverse transcriptase
(Gibco-BRL) with oligo(dT) ${ }_{12-18}$ primer for $55 \mathrm{~min}$ at $70{ }^{\circ} \mathrm{C}$ and then chilled on ice. The generated cDNA was amplified with specific primers, various amounts of competitors constructed using Competitive DNA Construction Kit (Takara Shuzo Co., Ltd, Tokyo, Japan) and Taq DNA polymerase. PCR cycle parameters were $95{ }^{\circ} \mathrm{C}$ for $30 \mathrm{~s}, 62^{\circ} \mathrm{C}$ for $30 \mathrm{~s}$ and $72{ }^{\circ} \mathrm{C}$ for $60 \mathrm{~s}$, repeated for 33 cycles for EGF and EGF-R; and $95^{\circ} \mathrm{C}$ for $60 \mathrm{~s}, 60{ }^{\circ} \mathrm{C}$ for $60 \mathrm{~s}$ and $72{ }^{\circ} \mathrm{C}$ for $120 \mathrm{~s}$, repeated for 25 and 35 cycle for ER $\alpha$, and ER $\beta 1$ and ER $\beta 2$ respectively. The RT-PCR product was confirmed by digestion with PstI for EGF and ER $\alpha$, BglII for EGF-R, and AatII for ER $\beta 1$ and ER $\beta 2$. The RT-PCR product was electrophoresed on a $2 \%$ agarose gel, stained with ethidium bromide (EtBr), and photographed. Gel bands of amplified target and competitor were quantified by SCION Image Version 1.55 (Scion Co., Frederick, MD, USA) software and the ratio of target to competitor was calculated.

\section{Statistics}

Statistical analysis was carried out by Duncan's multiple comparison test for cell proliferation in Müllerian epithelium and mesenchyme during fetal development. Student's t-test or Welch's $t$-test was performed in cases of equal variance or unequal variance respectively, after ANOVA between GD 15.5 and 17.5 for cell proliferation in the Wolffian epithelium and mesenchyme. To determine the presence of significance for DES effects on cell proliferation and gene expression, data were analyzed by ANOVA followed by Student's $t$-test or Welch's $t$-test in cases of equal variance or unequal variance respectively. Data are reported as means \pm S.E.M. and considered significantly different at $P<0 \cdot 05$.

\section{Results}

\section{Cell proliferation}

Cell proliferation was evaluated by BrdU immunostaining in the developing female rat reproductive tract. BrdUlabeled cells were detected in epithelial and mesenchymal cells in both Müllerian and Wolffian ducts (Fig. 1). The percentage of BrdU-labeled cells in the Müllerian epithelium and mesenchyme are shown in Fig. $2 \mathrm{~A}$ and $\mathrm{B}$ respectively. On GD $15 \cdot 5$, cell proliferation was high at $32-40 \%$ in both epithelium and mesenchyme in the proximal and middle regions of the Müllerian duct (Fig. $2 \mathrm{~A}$ and $\mathrm{B})$. In the caudal region, the Müllerian duct is not yet formed by GD $15 \cdot 5$. However, by GD $17 \cdot 5$, Müllerian epithelial and mesenchymal cell proliferation was high and similar in the caudal and middle Müllerian duct regions (Fig. 2A and B). Both epithelial and mesenchymal cell proliferation was decreased dramatically in the proximal region on GD $17 \cdot 5$ and in the middle and caudal regions by GD 19.5 and 21.5 in the Müllerian duct (Fig. 2A and $\mathrm{B})$. 

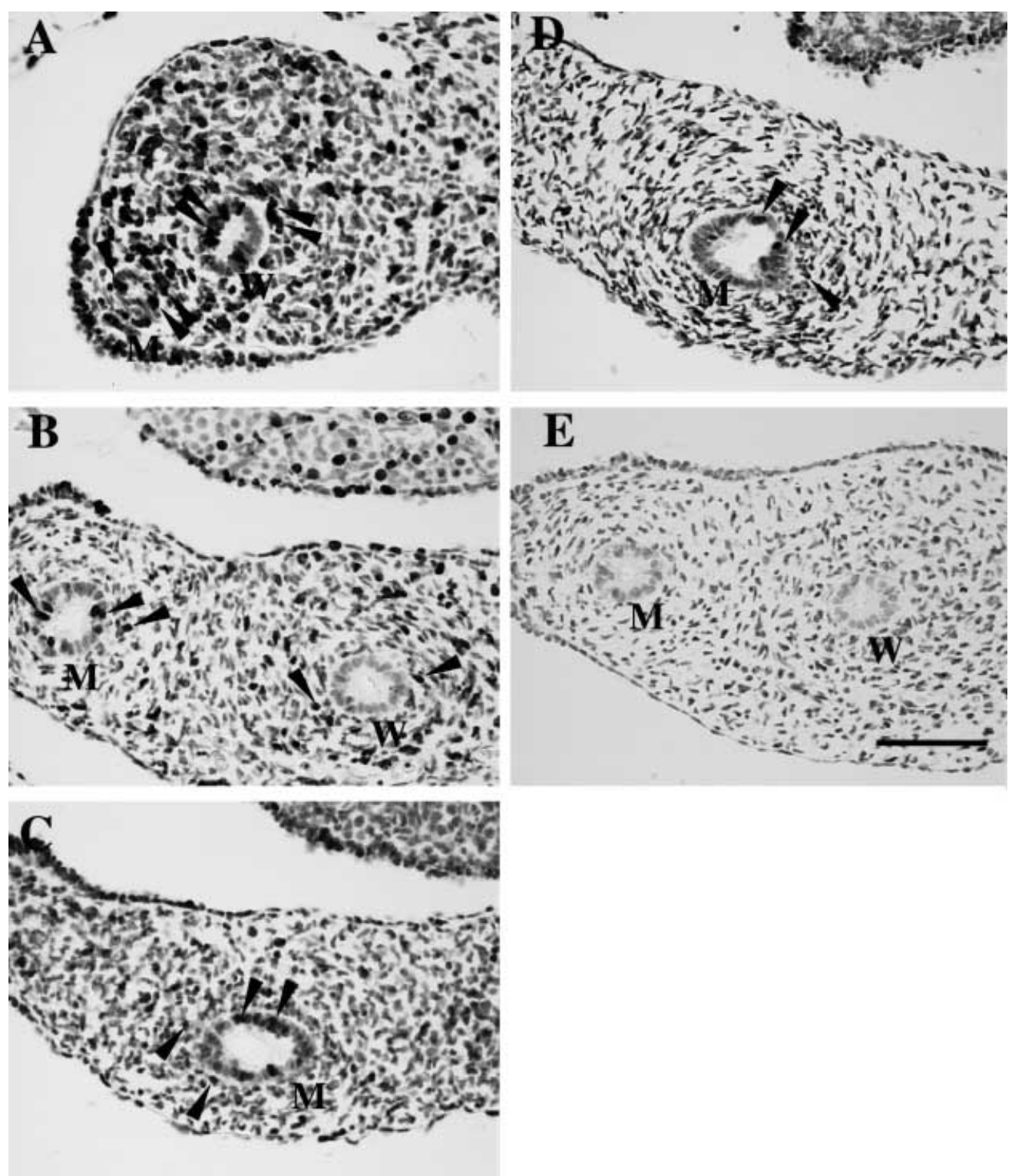

Figure $1 \mathrm{BrdU}$ immunostaining in the proximal reproductive tract of fetal female rats on GD 15.5 (A), GD 17.5 (B), GD $19 \cdot 5$ (C) and GD 21.5 (D). BrdU-labeled cells were detected in epithelial and mesenchymal cells in both Müllerian and Wolffian ducts (arrows). Staining was abolished by incubating with PBS instead of primary antibody (E). M: Müllerian duct, W: Wolffian duct. Bar: $50 \mu \mathrm{m}$.

Cell proliferation levels in the Wolffian epithelium and mesenchyme are shown in Fig. 2C and D respectively. On GD $15 \cdot 5$, cell proliferation in the Wolffian epithelium and mesenchyme was high at $22-36 \%$ and $31-38 \%$ respectively in all regions (Fig. 2C and D). On GD 17.5, cell proliferation in the Wolffian mesenchyme remained high at $20-33 \%$ in all regions, but epithelial proliferation dramatically decreased to $3 \cdot 0 \pm 0 \cdot 54,8 \cdot 8 \pm 1 \cdot 78$ and $21 \cdot 0 \pm 1 \cdot 36 \%$ in proximal, middle and caudal regions respectively (Fig. 2C and D). By GD 19.5, the Wolffian duct had degenerated and could not be observed in the specimen.

\section{Ontogenetic immunolocalization of EGF}

Staining specificity of polyclonal anti-EGF antibody is illustrated in Fig. 3. Positive staining was detected in the glandular convoluted tubule cells of submandibular glands 
A

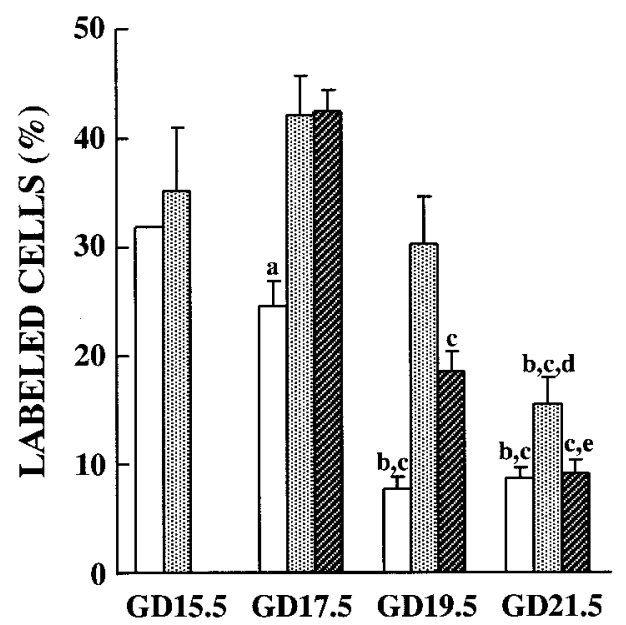

C

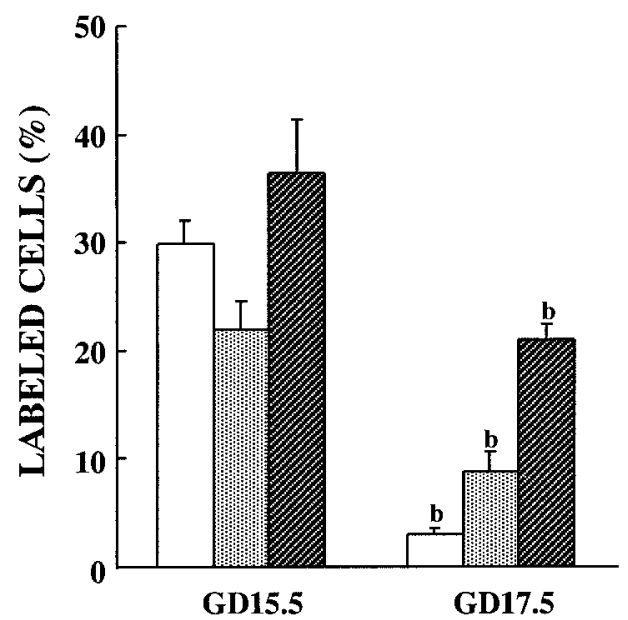

B

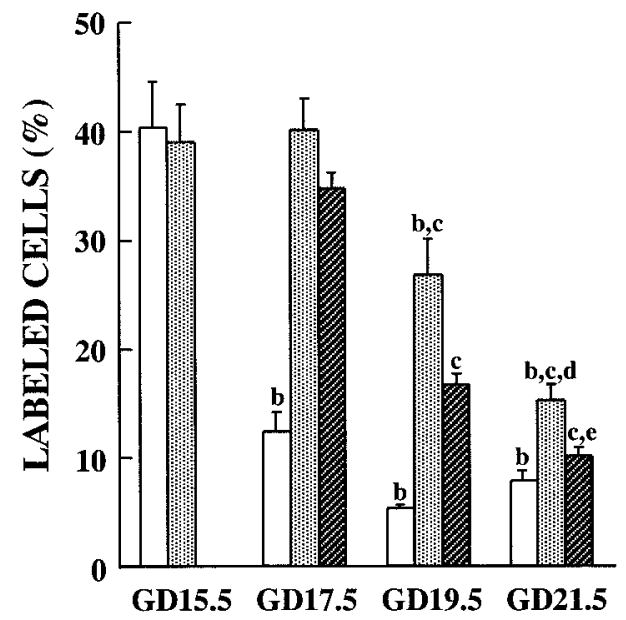

D

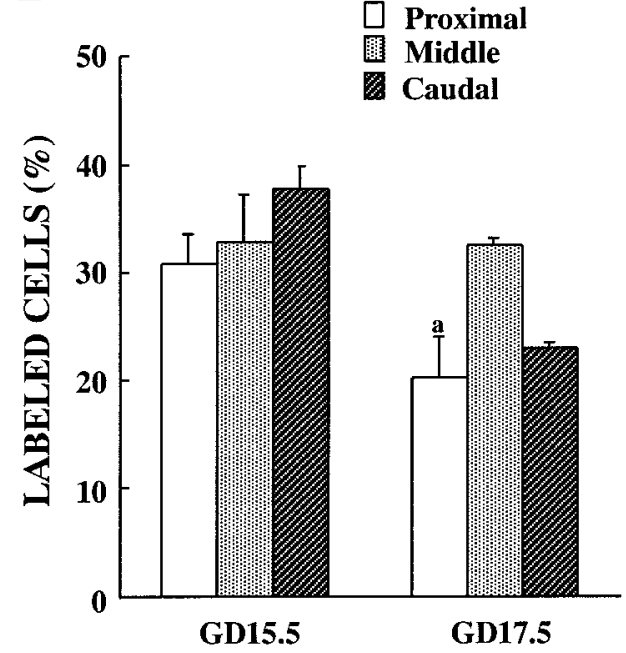

Figure 2 Cell proliferation of Müllerian epithelium (A), Müllerian mesenchyme (B), Wolffian epithelium (C) and Wolffian mesenchyme (D) during fetal rat development in the absence of DES. The caudal Müllerian duct region was not yet formed by GD 15.5 (A, B). Cell proliferation in Müllerian epithelium and Müllerian mesenchyme decreased in all regions with development. In the Wolffian duct, epithelial proliferation decreased sharply in all regions on GD 17.5 compared with GD 15.5. The Wolffian duct had fully regressed by GD 19.5 (C, D). Data are represented as means \pm S.E.M. $(n=6)$. a and b: $P<0.05$ and $P<0.01$ vS GD 15.5 respectively. C: $P<0 \cdot 01$ vs GD $17 \cdot 5$. $d$ and $e: P<0 \cdot 05$ and $P<0 \cdot 01$ vs GD $19 \cdot 5$ respectively. The S.E.M. value for GD $15 \cdot 5$ in $(A)$ is very small and cannot be depicted.

from adult male rats and confirmed EGF immunoreactivity (Poulsen et al. 1986, Fig. 3B). No positive immunoreactivity was detected when the specimen was incubated with normal rabbit immunoglobulin or preabsorbed anti-EGF antibody (Fig. 3A and C), confirming antibody specificity.

Ontogeny of EGF protein expression in the female rat reproductive tract is summarized in Table 1. Cell-typespecific expression of EGF was observed. In the Müllerian duct, epithelial cells in the proximal and middle regions showed intense EGF staining on GD 15.5 and $17 \cdot 5$, and staining remained intense in the proximal region on GD $19 \cdot 5$ (Fig. 4A, B, D, E and G). In the caudal Müllerian epithelium, EGF staining was weak on GD $17 \cdot 5$, and was also weak in the middle and caudal regions on GD $19 \cdot 5$ and throughout all regions by GD 21.5 (Fig. 4F, H-L). On the other hand, Wolffian epithelial cells showed marked immunoreactivity on GD 15.5 and 17.5 in all regions 

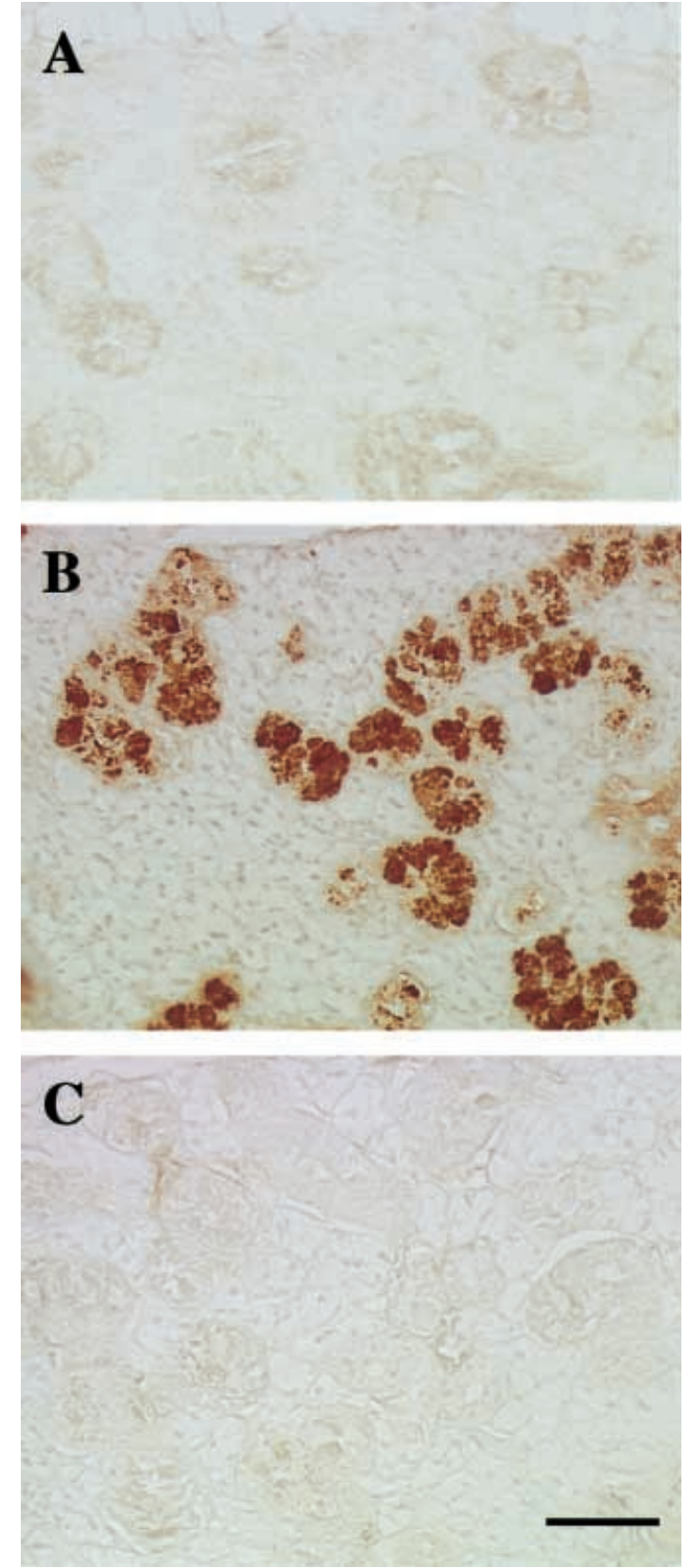

Figure 3 Staining specificity of polyclonal anti-rat EGF antibody. Paraffin sections of submandibular glands of adult male rat immunostained with normal rabbit serum (A), anti-EGF antibody (B) or anti-EGF antibody pre-absorbed with EGF peptide (C). Positive immunostaining was detected in the granular convoluted tubule cells (B). No immunostaining was observed with normal rabbit serum (A), or with pre-absorbed antibody $(\mathrm{C})$. Bar: $50 \mu \mathrm{m}$.

except for the caudal region on GD $17 \cdot 5$ (Fig. 4A-F). Mesenchymal cells in both the Müllerian and Wolffian ducts showed weak or no EGF staining in all regions during the examination period (GD 15.5-21.5).
Table 1 Ontogenetic immunolocalization of EGF in the fetal female rat reproductive tract

\begin{tabular}{|c|c|c|c|c|}
\hline & GD & Region & Epithelium & Mesenchyme \\
\hline \multirow[t]{12}{*}{ Müllerian duct } & $15 \cdot 5$ & Proximal & + & \pm \\
\hline & & Middle & + & \pm \\
\hline & & Caudal & $\mathrm{NF}$ & $\mathrm{NF}$ \\
\hline & $17 \cdot 5$ & Proximal & + & - \\
\hline & & Middle & + & \pm \\
\hline & & Caudal & \pm & \pm \\
\hline & $19 \cdot 5$ & Proximal & + & - \\
\hline & & Middle & \pm & \pm \\
\hline & & Caudal & \pm & \pm \\
\hline & $21 \cdot 5$ & Proximal & \pm & - \\
\hline & & Middle & \pm & - \\
\hline & & Caudal & \pm & - \\
\hline \multirow[t]{6}{*}{ Wolffian duct } & $15 \cdot 5$ & Proximal & + & \pm \\
\hline & & Middle & + & \pm \\
\hline & & Caudal & + & \pm \\
\hline & $17 \cdot 5$ & Proximal & + & \pm \\
\hline & & Middle & + & \pm \\
\hline & & Caudal & \pm & \pm \\
\hline
\end{tabular}

+: marked staining; \pm : slight staining; - : not detected; NF: not formed.

\section{Effects of prenatal DES exposure}

Effects of DES $(100 \mu \mathrm{g} / \mathrm{kg}$, GD 15-19) on cell proliferation was examined in the Müllerian duct on GD 19.5. Cell proliferation was altered by DES in a region- and cell-type-specific manner. In the proximal region, a 2- to 3 -fold increase in cell proliferation was observed in DESexposed Müllerian epithelium and mesenchyme, compared with oil-exposed tissues (Fig. 5). In contrast, DES decreased cell proliferation in the caudal epithelium (Fig. 5). DES had no effect on cell proliferation in mesenchymal cells in the caudal region or in epithelial and mesenchymal cells in the middle region (Fig. 5).

To understand the effects of DES on EGF and ER $\alpha$ expression in the fetal female rat reproductive tract, immunohistochemistry was performed in control and DES-exposed tissues on GD 19.5. DES inhibited EGF expression in the Müllerian epithelium in both the proximal and middle regions, but no influence was observed in the Müllerian mesenchyme (Fig. 6). Positive nuclear staining of ER $\alpha$ was detected in the Müllerian duct using monoclonal anti-ER $\alpha$ antibody. Binding specificity of the antibody to rat ER $\alpha$ was previously evaluated by Fisher et al. (1997). To confirm binding specificity in the present study, adult rat uterus and ovary were immunostained with this antibody. In uterus, intense staining was observed in both luminal and glandular epithelia and in stromal and myometrial tissues (Fig. 7A). In ovary, theca cells, interstitial cells and germinal epithelia also showed intense staining (Fig. 7B). ER $\alpha$ staining was abolished by incubation with normal mouse IgG1 in uterus (Fig. 7C) and ovary (Fig. 7D). These observations were in agreement with previous reports (Hiroi et al. 1999, Pelletier 

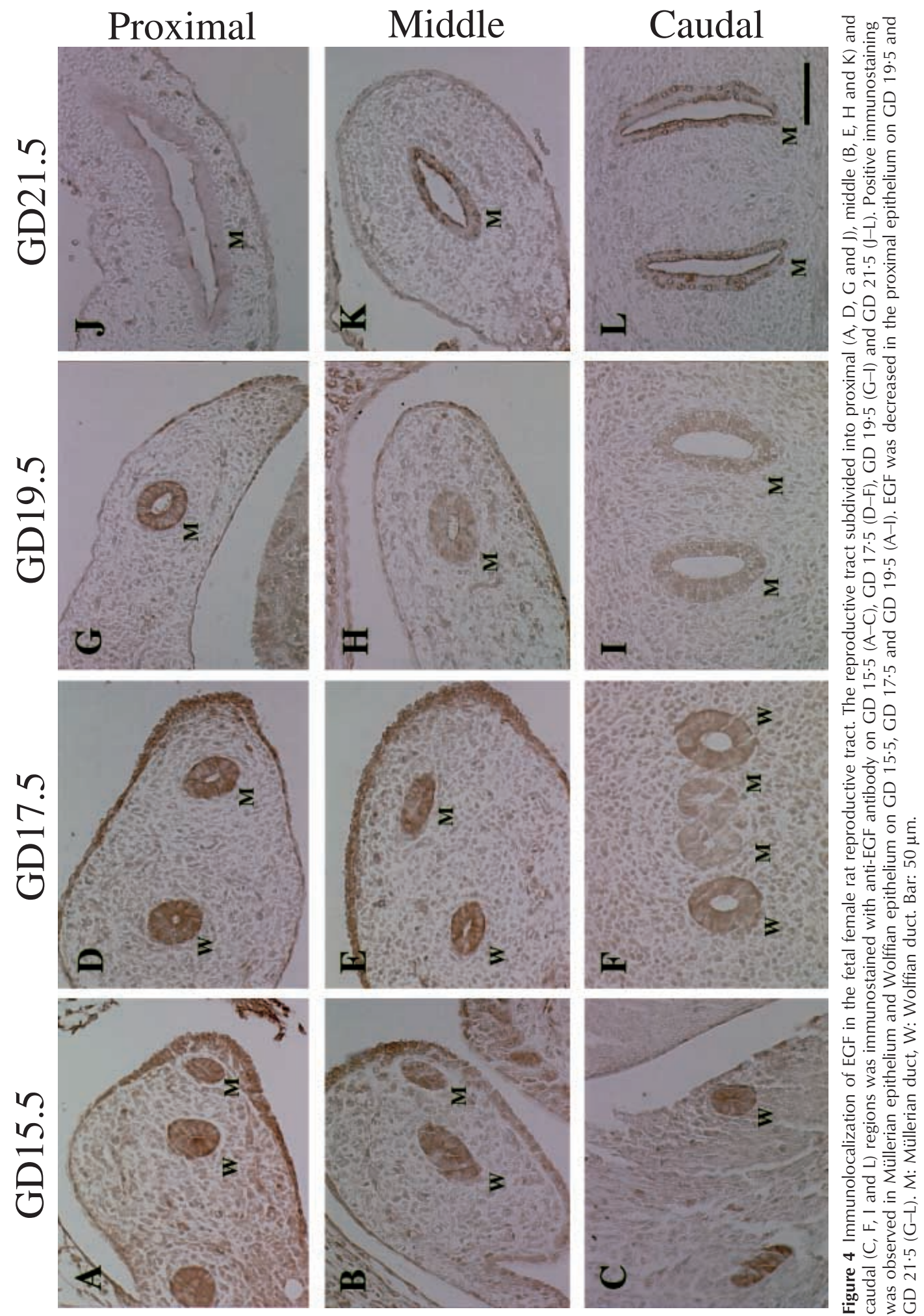


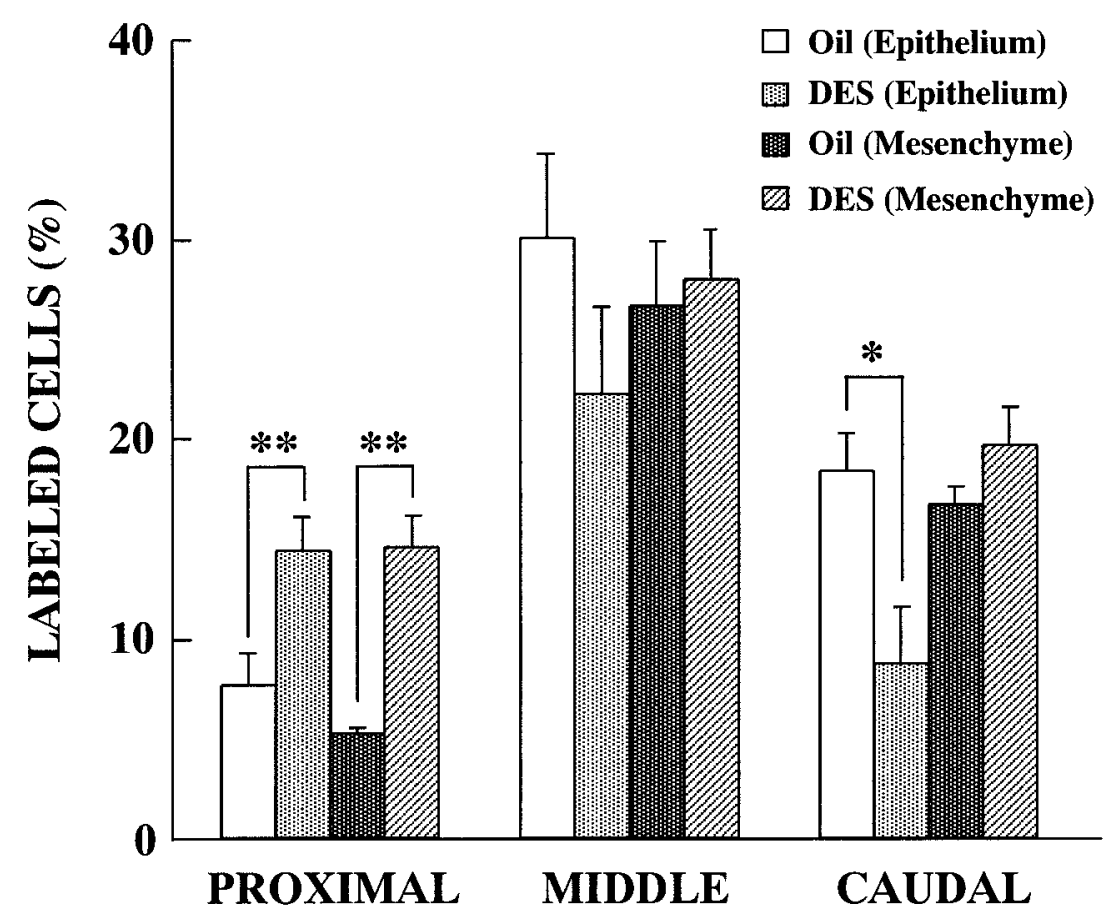

Figure 5 Effect of DES on cell proliferation in the GD 19.5 Müllerian ducts. DES stimulated cell proliferation in epithelium and mesenchyme of the proximal region, but reduced it in epithelium of the caudal region. Data are represented as means \pm S.E.M. $(n=3-6) .{ }^{*} P<0 \cdot 05$, ${ }^{*} P<0 \cdot 01$.

et al. 2000). In the oil-exposed GD $19 \cdot 5$ reproductive tract, positive immunoreactivity for ER $\alpha$ was localized mainly in the proximal Müllerian epithelium, and in Müllerian mesenchyme in the middle and caudal regions (Fig. 8A-C). DES did not affect ER $\alpha$ expression (Fig. 8D-F).

Competitive RT-PCR was employed to examine DES influence on expression of mRNAs encoding EGF, EGF-R, ER $\alpha, E R \beta 1$ and ER $\beta 2$ in the fetal female rat Müllerian duct. The primers used in this study are shown in Table 2. Amplified products of all target genes using these primers were detected in oil-exposed tissues, but they were abolished by omitting the reverse transcriptase, and were digested with specific restriction enzymes to the expected fragment sizes (data not shown). For quantification, the $\log$ ratio of target vs competitor was plotted against competitor DNA copy numbers. The plotted curves are shown by linear regression (Fig. 9). DES significantly inhibited expression of EGF, ER $\beta 1$ and $\operatorname{ER} \beta 2(60 \pm 6 \cdot 8,41 \pm 12 \cdot 8$ and $53 \pm 2 \cdot 9 \%$ respectively vs the oil group), but not that of ER $\alpha$ and EGF-R (Fig. 10).

\section{Discussion}

In the present study, region-specific ontogenetic changes in cell proliferation and EGF immunolocalization were examined in the fetal female rat reproductive tract. The findings described provide highly relevant characterization of the pattern and correlation of changes in cell proliferation and EGF expression during normal gestational development in the rat. Inhibitory effects of DES on EGF, ER $\beta 1$ and ER $\beta 2$ expression were shown by immunohistochemistry and/or competitive RT-PCR. These results will serve to better understand the mechanism of DES effects on female reproductive tracts in mammals.

In female fetuses, the Wolffian duct has regulatory influences on early development of the Müllerian duct, which develops in a cranial to caudal direction during gonad formation (Dohr \& Tarmann 1984, Byskov \& Høyer 1994). In this study, the Müllerian duct was not yet formed at the caudal region, while the proximal and middle regions had high proliferative activity on GD $15 \cdot 5$. By GD 17.5, the caudal region of the Müllerian duct had formed and showed high proliferation. Morphogenesis of the proximal Müllerian duct may have been completed on GD $17 \cdot 5$, since a dramatic decrease in cell proliferation was observed. On GD 19.5 and 21.5 , decreases in cell proliferation were also observed in the middle and caudal Müllerian duct, indicating a termination of primary morphogenesis.

In mice, cell proliferation indicated by $\left[{ }^{3} \mathrm{H}\right]$ thymidine incorporation and immunohistochemical staining of proliferating cell nuclear antigen occurred in more than $95 \%$ 
Oil
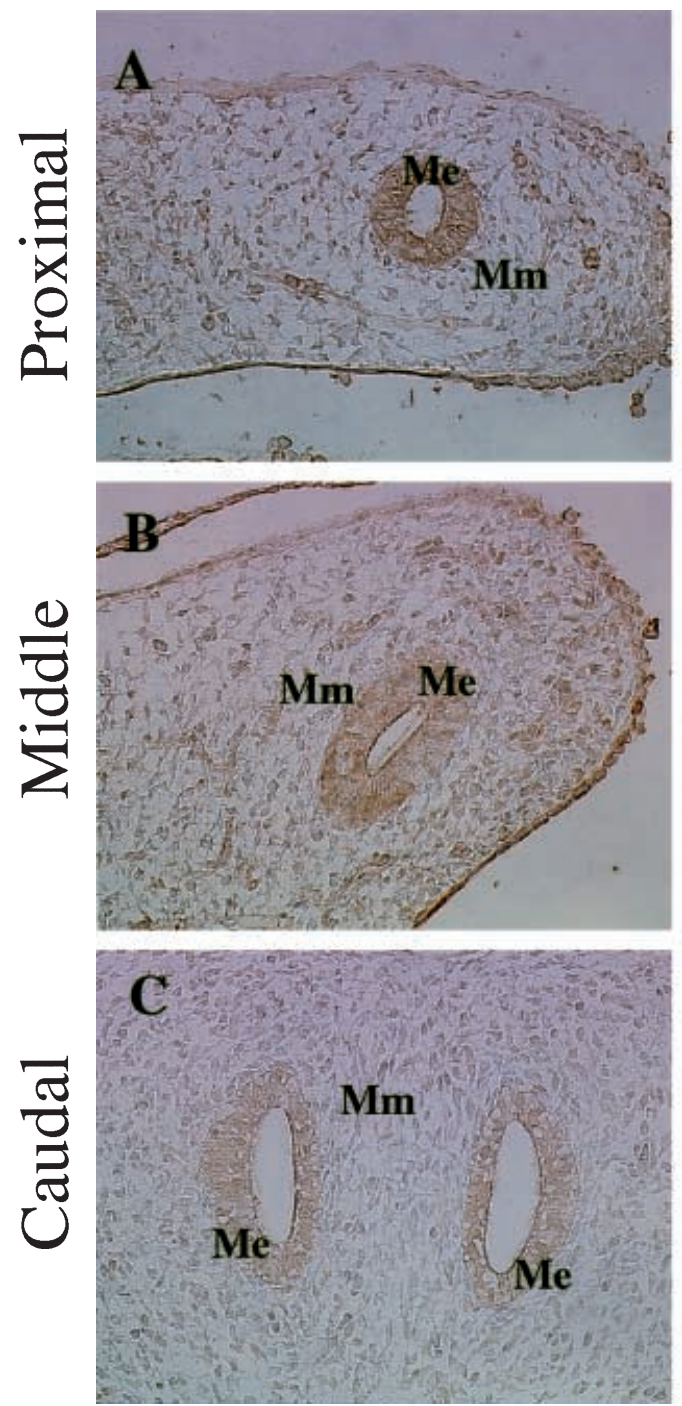

DES
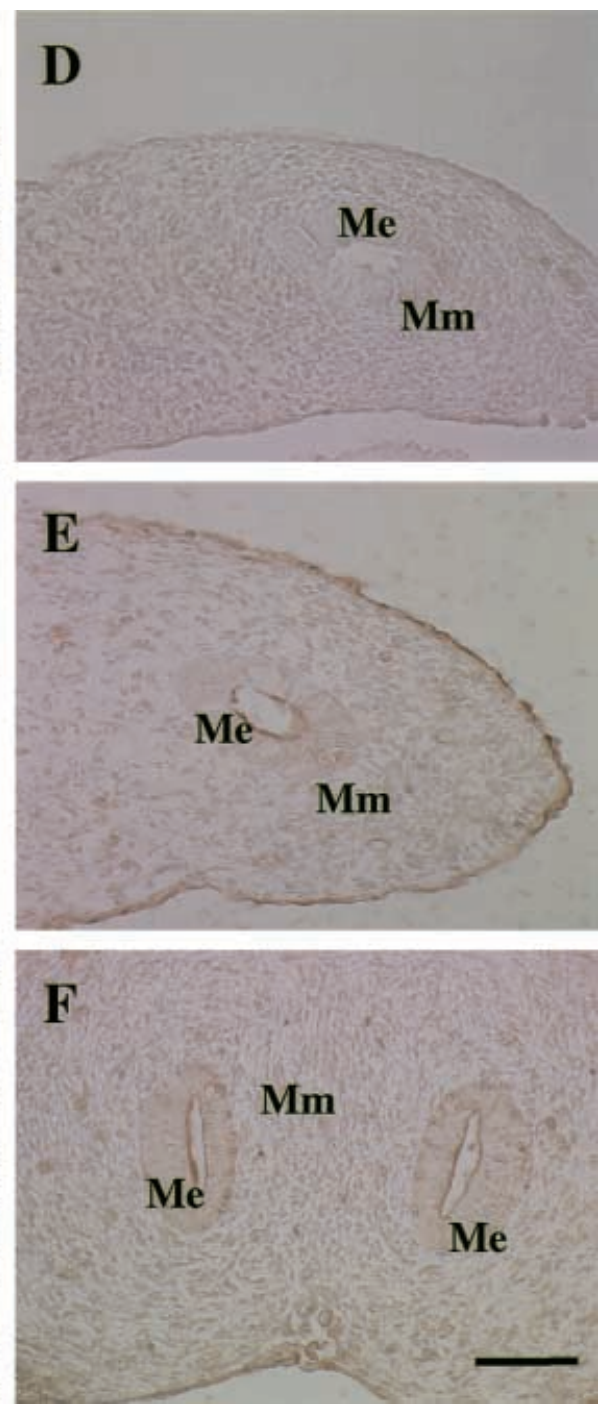

Figure 6 Effect of DES on EGF expression in the GD 19.5 Müllerian ducts. Positive epithelial EGF immunostaining was observed in the proximal, middle and caudal regions in the oil group (A-C). DES reduced epithelial EGF expression (D-F). Me: Müllerian epithelium, Mm: Müllerian mesenchyme. Bar: $50 \mu \mathrm{m}$.

of uterine cells and more than $80 \%$ of oviduct cells on postnatal day 1 (Li 1994). Therefore, it was hypothesized that cell proliferation in the rat Müllerian duct would be high and then decrease during morphogenesis from mid to late gestation. Subsequently, the developing reproductive tract would show high proliferative activity again during morphological and functional differentiation after birth. Although the Wolffian duct regresses in females, cell proliferation in the Wolffian epithelium and mesenchymal stroma showed high proliferation, similar to the Müllerian duct on GD $15 \cdot 5$. On GD $17 \cdot 5$, the Wolffian duct had started to degenerate, and as a result showed a decrease in cell proliferation. It is conceivable that there may be a critical time point for induction of Wolffian duct degeneration between GD 15.5 and $17 \cdot 5$, initiated in the absence of androgens (Josso \& Picard 1986).

In male fetuses, testicular androgens regulate cell proliferation and differentiation of the Wolffian duct (Byskov \& Høyer 1994). The promoting effect of androgens on cell proliferation is mediated by EGF in Wolffian duct organ culture (Gupta et al. 1991). In female fetuses, however, primary and essential factors which regulate cell proliferation and differentiation of the Müllerian duct have not yet been identified either in vitro or in vivo. EGF and 

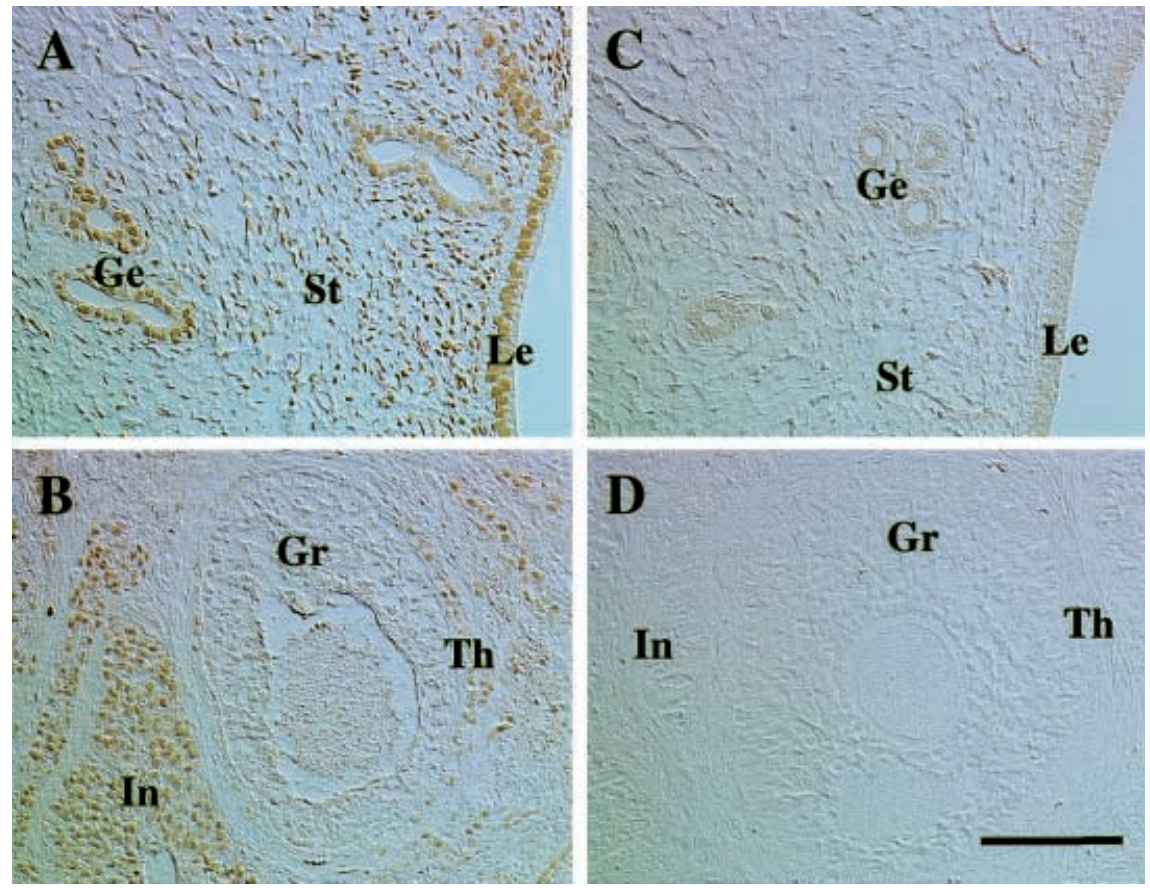

Figure 7 Immunohistochemical staining of ER $\alpha$ in adult rat uterus and ovary. In uterus (A) nuclei stained positive for ER $\alpha$ in luminal epithelium (Le), glandular epithelium (Ge), stroma (St) and myometrium. In ovary (B), ER $\alpha$ nuclear staining was seen in theca cells (Th), interstitial cells (In) and germinal epithelium, but not granulosa cells (Gr). Immunoreactivities of ER $\alpha$ and ER $\beta$ were abolished by incubation with normal mouse IgG1 in uterus (C) and ovary (D). Bar: $100 \mu \mathrm{m}$.

insulin-like growth factor (IGF)-I stimulate cell proliferation in immature mouse uterine and vaginal epithelial cells in vitro (Tomooka et al. 1986, Iguchi et al. 1987, Shiraga et al. 1997, 2000). Because estrogen stimulates uterine epithelial cell proliferation (McCormack \& Glasser 1980, Quarmby \& Korach 1984) and expression of EGF, IGF-I, heparin-binding EGF-like growth factor, transforming growth factor (TGF)- $\alpha$ and EGF-R in the reproductive tracts of mice and rats, these growth factors may mediate the estrogen-induced proliferative and differentiative responses in rodent reproductive tracts (Murphy et al. 1987, DiAugustine et al. 1988, Nelson et al. 1991, 1992, Beck \& Garner 1992, Ignar-Trowbridge et al. 1992, Kapur et al. 1992, Das et al. 1994, Sahlin et al. 1994, Zhang et al. 1994, 1998, Falck \& Forsberg 1996, Hom et al. 1998). In the fetal reproductive tract, expression of EGF-R in mice (Bossert et al. 1990), and EGF, TGF- $\beta$ and IGF-I in rats (Koike \& Noumura 1993, Kanno et al. 1994, Gu et al. 1999) was reported. Kanno et al. (1994) reported that immunoreactivity of EGF was not-detected, moderate, slight and moderate during GD 15, GD 16-17, GD 18-20 and GD 21 respectively, in the female rat Müllerian duct. They also reported that no immunoreactivity for EGF was detected in the Wolffian duct of fetal female rats. Differences in ontogenetic expression of EGF between Kanno et al. (1994) and the present study may be due to differences in polyclonal antibodies used. In the present study, a parallel decrease between cell proliferation and EGF expression was observed, suggesting that EGF may be a primary factor necessary for regulation of Müllerian duct cell proliferation in fetal female rats.

A variety of reproductive tract abnormalities occurred in young women whose mothers received DES during the first trimester of pregnancy (Herbst et al. 1971, Herbst \& Bern 1981). Perinatal treatment of mice and rats with DES also causes a variety of abnormalities in the Müllerian derivatives (Boylan 1978, McLachlan et al. 1980, Newbold et al. 1983a,b, 1984, Rothschild et al. 1987/88, Ozawa et al. 1991). While the rodent Müllerian duct involves simple straight tubes lined with a single-layered epithelium from proximal to caudal regions during prenatal life, region-specific effects of DES were found in the developing Müllerian duct, suggesting the developmental presence of different functional mechanisms for cell growth and differentiation in the various fetal Müllerian duct regions. In addition, the present study also showed cell-type-specific DES effects on cell proliferation of the Müllerian duct such as a stimulatory effect in epithelium and mesenchymal stroma at the proximal region and an inhibitory effect in epithelium at the caudal region. 
Oil
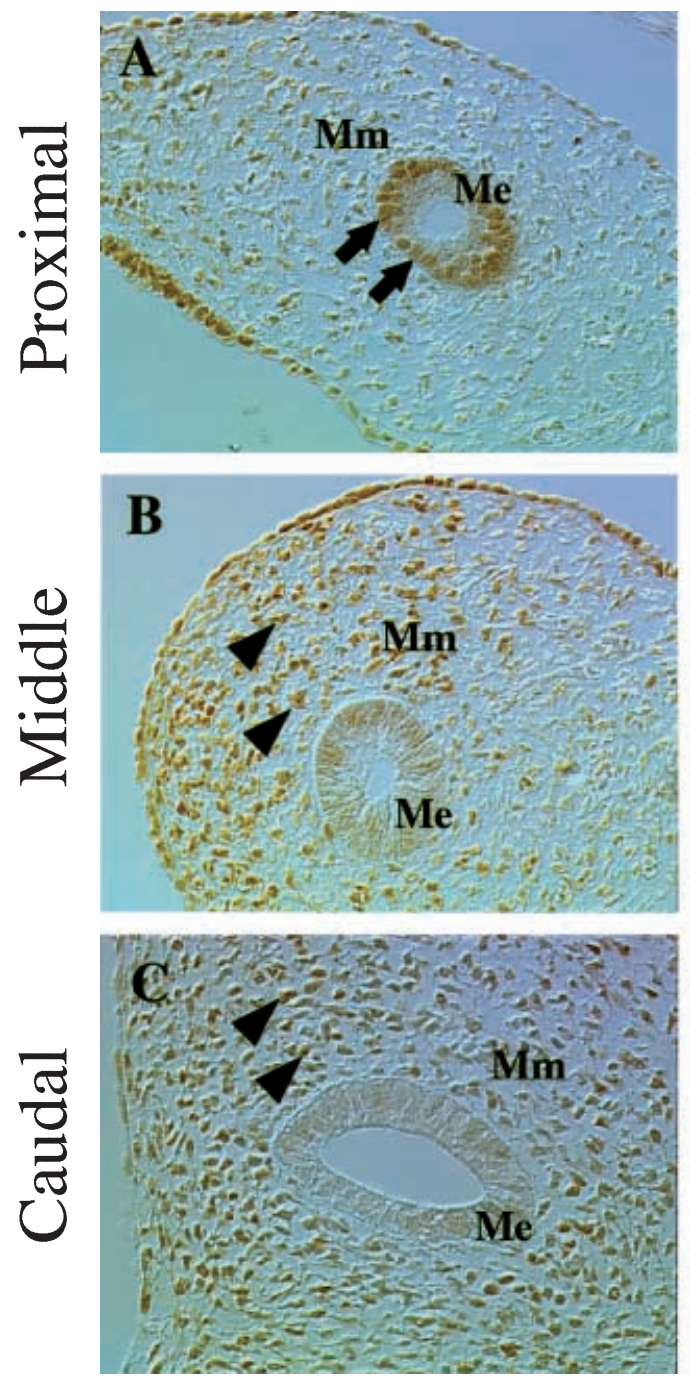

DES
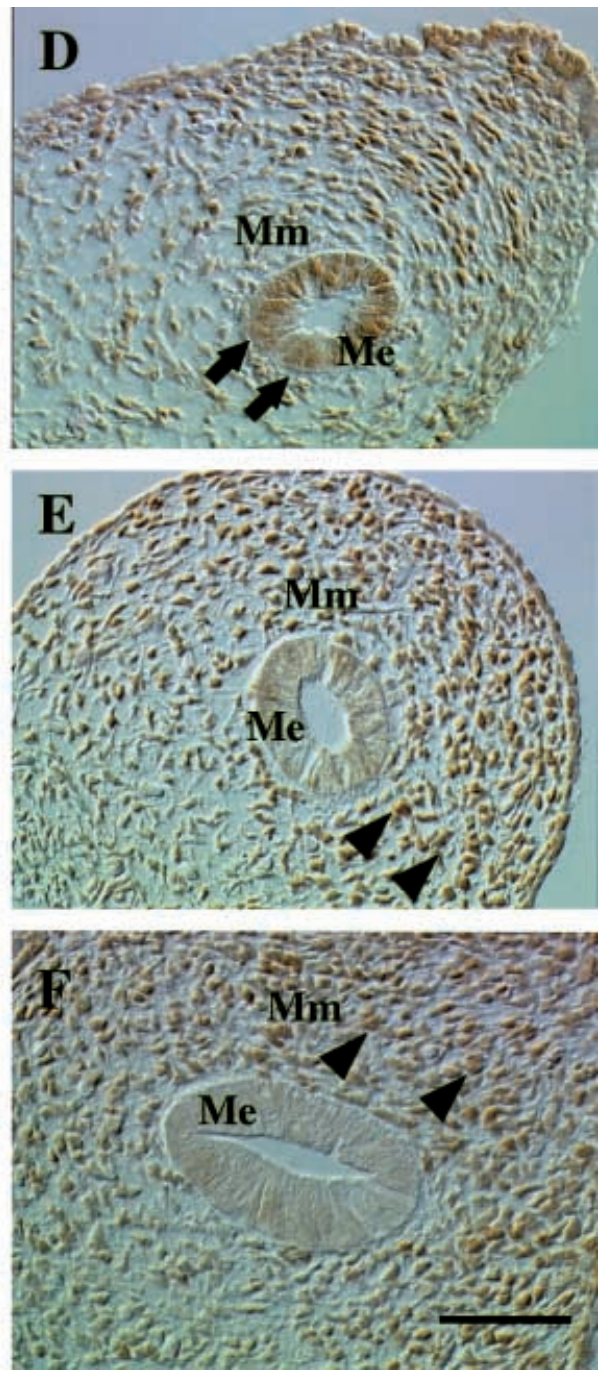

Figure 8 Effect of DES on ER $\alpha$ expression in the GD 19.5 Müllerian ducts. In the oil group, nuclear ER $\alpha$ immunostaining was intense mainly in epithelium of the proximal region (A) and mesenchyme of the middle and caudal regions (B, C). DES had no effect on ER $\alpha$ expression in any region (D-F). Arrow: positive nuclear epithelial staining; arrowhead: positive nuclear mesenchymal staining. Me: Müllerian epithelium, Mm: Müllerian mesenchyme. Bar: $50 \mu \mathrm{m}$.

The role of ERs in the effects of DES has been demonstrated (Greco et al. 1993, Couse et al. 1997). Two subtypes of ERs have been identified in rats, ER $\alpha$ (Koike et al. 1987) and ER $\beta$ (Kuiper et al. 1996). The physiological significance of ERs in the development and differentiation of the reproductive tract has not yet been clarified; however, the importance of ERs was suggested from the phenotypes of ER knockout (ERKO) mice, $\alpha$ ERKO, $\beta E R K O$ and $\alpha \beta E R K O$ (Lubahn et al. 1993, Krege et al. 1998, Couse \& Korach 1999, Couse et al. 1999). Although different expression of $\operatorname{ER} \alpha$ and $\operatorname{ER} \beta$ were demonstrated during mouse embryogenesis in various organs including those of the reproductive tract (Lemmen et al. 1999, Jefferson et al. 2000, Nielsen et al. 2000), mouse reproductive tract development is essentially normal during the prenatal and the neonatal stages in $\alpha$ ERKO, $\beta$ ERKO and $\alpha \beta E R K O$ mice, suggesting that signaling through the ERs is not necessary for female reproductive tract morphogenesis. Nonetheless, the estrogen stimulatory effect on cell growth was not found in the female reproductive tract of $\alpha E R K O$ mice (Couse \& Korach 1999). Thus, prenatally exposed DES could act 
Table 2 PCR primers for the detection of various gene expressions used in this study

\begin{tabular}{|c|c|c|c|c|}
\hline & Direction & Sequence $\left(5^{\prime}-3^{\prime}\right)$ & $\begin{array}{l}\text { Amplified } \\
\text { length }(b p)\end{array}$ & $\begin{array}{l}\text { Genbank } \\
\text { Accession No. }\end{array}$ \\
\hline \multicolumn{5}{|l|}{ Gene } \\
\hline \multirow[t]{2}{*}{ EGF } & Forward & AGCCATGCССАСТGTATTTC & & \\
\hline & Reverse & CCACCACACAGACAGACACC & 598 & U04842 \\
\hline \multirow[t]{2}{*}{ EGF-R } & Forward & GTGTGTGCAGATTGCAAAGG & & \\
\hline & Reverse & TAATGCAAGCCACAGTGGAA & 701 & M37394 \\
\hline \multirow[t]{2}{*}{$\mathrm{ER} \alpha$} & Forward & AAGAGAAGGACCACATCCACC & & \\
\hline & Reverse & GGAATGTGCTGAAGTGGAGC & 326 & Y00102 \\
\hline \multirow[t]{2}{*}{$\mathrm{ER} \beta 1$} & Forward & TTCTGGACAGGGATGAGGG & & \\
\hline & Reverse & GGGACCACATTTTTGCACTT & 376 & AF042058 \\
\hline \multirow[t]{2}{*}{$E R \beta 2$} & Forward & GTCСТCAGAAGACССТСАСТGG & & \\
\hline & Reverse & GGGACCACATTTTTGCACTT & 420 & AF042059 \\
\hline
\end{tabular}
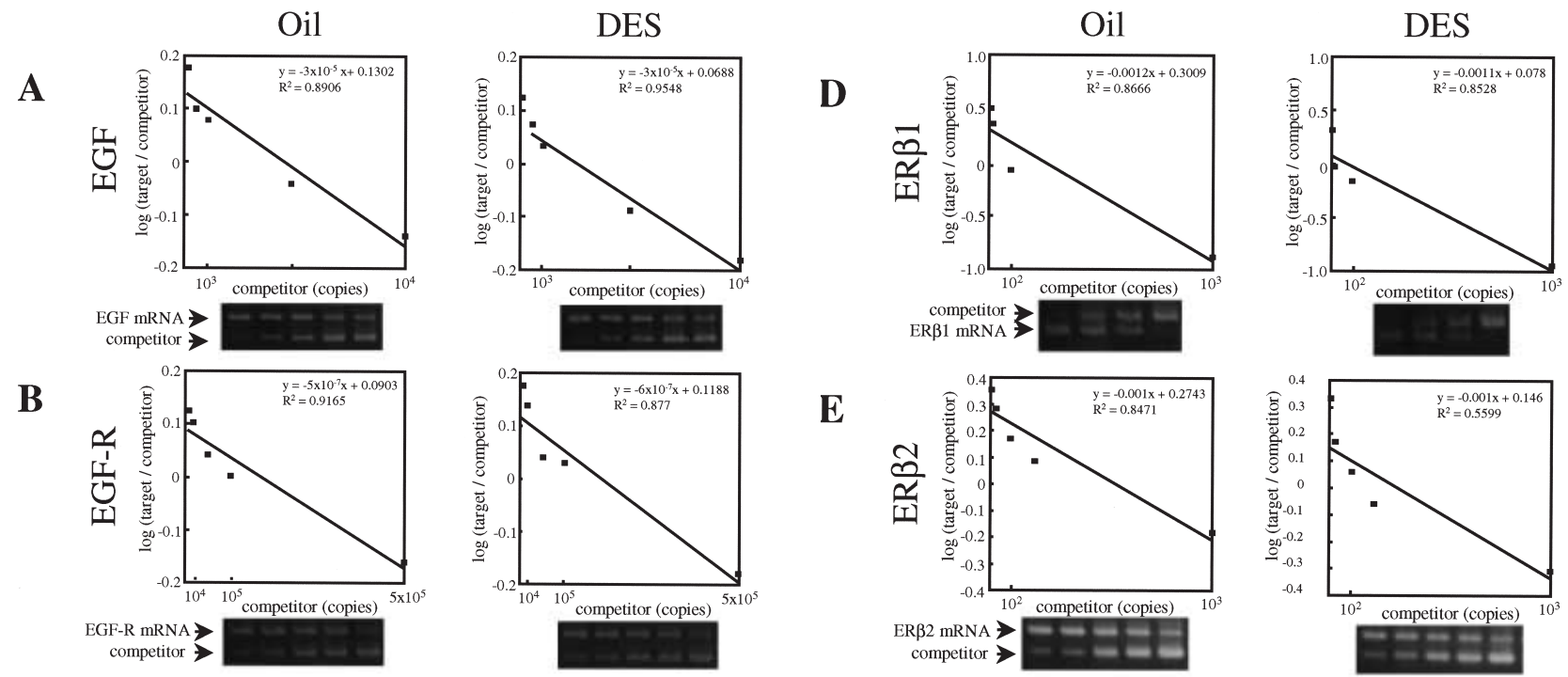

$\mathbf{C}$
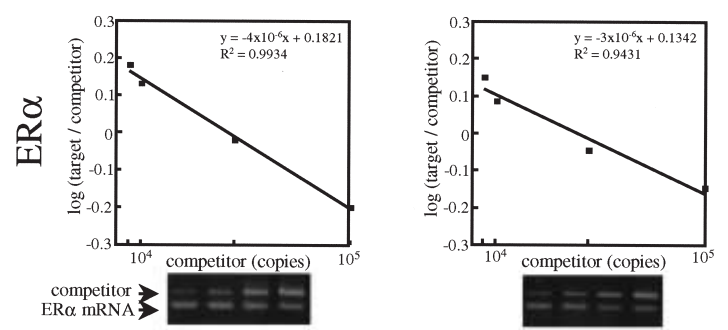

Figure 9 Competitive RT-PCR of (A) EGF, (B) EGF-R, (C) ER $\alpha$, (D) ER $\beta 1$ and (E) ERß2 mRNAs. Left panels are oil group, right panels DES group. Reverse-transcribed total RNA isolated from the GD 19.5 reproductive tracts (approximately 20 fetuses per group) were co-amplified with serially diluted competitor. The RT-PCR products were electrophoresed and stained with EtBr. The densities of competitor bands and target bands were quantified and the log ratio of target vs competitor was plotted against copy numbers for competitor DNA. The standard curves were obtained by linear regression. On the standard curve, the point where the log ratio equaled 0 (target/competitor $=1$ ) is considered the concentration of the reverse-transcribed mRNA.

through ERs to cause abnormalities in the female reproductive tract. In the present study, ER $\alpha, E R \beta 1$ and ER $\beta 2$ were detected in the GD $19 \cdot 5$ reproductive tract of female rats by immunohistochemistry and/or competitive RTPCR. This is the first report showing ER $\alpha, E R \beta 1$ and ER $\beta 2$ expression in the fetal female rat reproductive tract.
Altered expression of ER $\alpha$ but not ER $\beta$ was reported in adult male and female reproductive tracts after neonatal DES treatments in mice and rats (Sato et al. 1994, 1996, Atanassova et al. 2001). In the present study, inhibitory effects of DES on ER $\beta 1$ and ER $\beta 2$ mRNA expression in the fetal rat reproductive tract were demonstrated by 

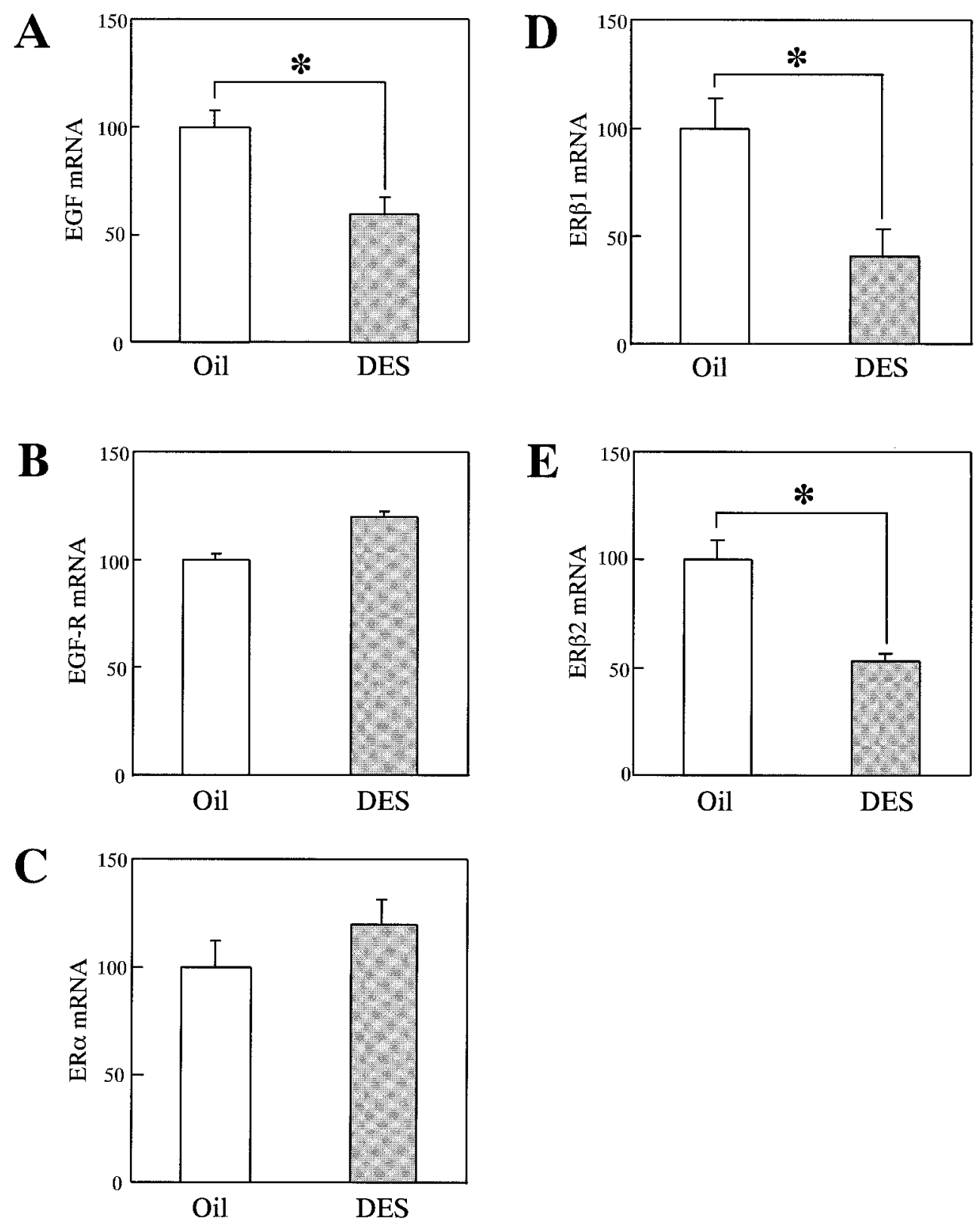

Figure 10 DES effects on Müllerian EGF(A), EGF-R (B), ER $\alpha(C), E R \beta 1$ (D) and ER $\beta 2$ (E) mRNA levels quantified by competitive RT-PCR. Expression levels in the oil group were designated as 100\%, and relative expression levels in the DES group are presented. Significant decreases in mRNA levels of EGF, ER $\beta 1$ and ER $\beta 2$ after DES were observed. No changes in EGF-R or ER $\alpha$ levels were observed after DES. Data are represented as means \pm S.E.M. from three independent experiments. ${ }^{*} P<0 \cdot 05$.

competitive RT-PCR. These inhibitory effects may be a result of down-regulation. DES did not alter ER $\alpha$ mRNA or protein. Therefore, it is hypothesized that DES may act mainly through ER $\beta 1$ and/or ER $\beta 2$ in the fetal reproductive tract.

To clarify the role of EGF in the fetal female reproductive tract after DES treatment, EGF and EGF-R were investigated by immunohistochemistry and/or competitive RT-PCR. DES did not alter EGF-R mRNA, but EGF protein and mRNA were inhibited in the Müllerian duct. However, there was no positive correlation between changes in EGF expression and cell proliferation following DES. Therefore, EGF may not mediate DES action and other growth factors should be considered. 
Recently, the correlation of Hox gene expression with reproductive tract morphogenesis was considered based on insights from studies of knockout mice (Satokata et al. 1995, Gendron et al. 1997, Warot et al. 1997). Hox genes are the vertebrate homologues of the Drosophila homeotic selector genes. The pattern and timing of genes of the Hoxa axis were demonstrated in the development of the Müllerian duct (Taylor et al. 1997). Effects of prenatal treatment of DES on Hoxa mRNA expression in vivo or in organ culture were examined (Ma et al. 1998, Block et al. 2000). In these studies, DES caused posterior shift and reduced expression in Hoxa-9, -10 and -11 in the Müllerian duct, suggesting a potential molecular explanation for teratogenic effects of DES in the developing reproductive tract. Studies clarifying the relationship of these genes with reproductive tract abnormalities caused by DES are needed.

In conclusion, the present study demonstrates that there is parallel relationship between cell proliferation and EGF expression in the Müllerian duct during normal fetal development, and that prenatal exposure to DES alters cell proliferation in a region- and cell-type-specific manner while inhibiting EGF, ER $\beta 1$ and ER $\beta 2$ expressions in the fetal reproductive tract of female rats.

\section{Acknowledgements}

The authors would like to thank Emeritus Professor Noboru Takasugi of Yokohama City University for his valuable advice and critical reading of this manuscript. The authors would also like to acknowledge Drs Hiroshi Suzuki, Shinji Usuda, Takanori Hanada, Toshiaki Matsuzawa and Michio Fujiwara and members of Safety Research Laboratories, Yamanouchi Pharmaceutical Co., Ltd for their helpful support and comments. This work was partly supported by a Grant-in-Aid for Scientific Research from the Ministry of Education, Science and Culture of Japan.

\section{References}

Atanassova N, McKinnell C, Williams K, Turner KJ, Fisher JS, Saunders PTK, Millar MR \& Sharpe RM 2001 Age-, cell- and region-specific immunoexpression of estrogen receptor alpha (but not estrogen receptor beta) during postnatal development of the epididymis and vas deferens of the rat and disruption of this pattern by neonatal treatment with diethylstilbestrol. Endocrinology 142 874-886.

Beck CA \& Garner CW 1992 Stimulation of DNA synthesis in rat uterine cells by growth factors and uterine extracts. Molecular and Cellular Endocrinology 84 109-118.

Block K, Kardana A, Igarashi P \& Taylor HS 2000 In utero diethylstilbestrol (DES) exposure alters Hox gene expression in the developing Müllerian system. FASEB Journal 14 1101-1108.

Bossert NL, Nelson KG, Ross KA, Takahashi T \& McLachlan JA 1990 Epidermal growth factor binding and receptor distribution in the mouse reproductive tract during development. Developmental Biology 142 75-85.
Boylan ES 1978 Morphological and functional consequences of prenatal exposure to diethylstilbestrol in the rat. Biology of Reproduction 19 854-863.

Byskov AG \& Høyer PE 1994 Embryology of mammalian gonads and duct. In The Physiology of Reproduction, edn 2, pp 487-540. Eds E Knobile \& JD Neill. New York: Raven Press.

Couse JF \& Korach KS 1999 Estrogen receptor null mice: what have we learned and where will they lead us? Endocrine Reviews $\mathbf{2 0}$ 358-417.

Couse JF, Davis VL, Hanson RB, Jefferson WN, McLachlan JA, Bullock BC, Newbold RR \& Korach KS 1997 Accelerated onset of uterine tumors in transgenic mice with aberrant expression of the estrogen receptor after neonatal exposure to diethylstilbestrol. Molecular Carcinogenesis 19 236-242.

Couse JF, Hewitt SC, Bunch DO, Sar M, Walker VR, Davis BJ \& Korach KS 1999 Postnatal sex reversal of the ovaries in mice lacking estrogen receptors $\alpha$ and $\beta$. Science 286 2328-2331.

Das SK, Tsukamura H, Paria BC, Andrews GK \& Dey SK 1994 Differential expression of epidermal growth factor receptor (EGF-R) gene and regulation of EGF-R bioactivity by progesterone and estrogen in the adult mouse uterus. Endocrinology 134 971-981.

DiAugustine RP, Petrusz P, Bell GI, Brown CF, Korach KS, McLachlan JA \& Teng CT 1988 Influence of estrogens on mouse uterine epidermal growth factor precursor protein and messenger ribonucleic acid. Endocrinology 122 2355-2363.

Dohr G \& Tarmann T 1984 Contacts between Wolffian and Müllerian cells at the tip of the outgrowing Müllerian duct in rat embryos. Acta Anatomica 120 123-128.

Falck L \& Forsberg JG 1996 Immunohistochemical studies on the expression and estrogen dependency of EGF and its receptor and c-fos proto-oncogene in the uterus and vagina of normal and neonatally estrogen-treated mice. Anatomical Record 245 459-471.

Fisher JS, Millar MR, Majdic G, Saunders PTK, Fraser HM \& Sharpe RM 1997 Immunolocalisation of oestrogen receptor- $\alpha$ within the testis and excurrent ducts of the rat and marmoset monkey from perinatal life to adulthood. Journal of Endocrinology 153 485-495.

Gendron RL, Paradis H, Hsieh-Li HM, Lee DW, Potter SS \& Markoff E 1997 Abnormal uterine stromal and glandular function associated with maternal reproductive defects in Hoxa-11 null mice. Biology of Reproduction 56 1097-1105.

Greco TL, Furlow JD, Duello TM \& Gorski J 1991 Immunodetection of estrogen receptors in fetal and neonatal female mouse reproductive tracts. Endocrinology 129 1326-1332.

Greco TL, Duello TM \& Gorski J 1993 Estrogen receptors, estradiol, and diethylstilbestrol in early development: the mouse as a model for the study of estrogen receptors and estrogen sensitivity in embryonic development of male and female reproductive tracts. Endocrine Reviews 14 59-71.

Gu Y, Branham WS, Sheehan DM, Webb PJ, Moland CL \& Streck RD 1999 Tissue-specific expression of messenger ribonucleic acids for insulin-like growth factors and insulin-like growth factor-binding proteins during perinatal development of the rat uterus. Biology of Reproduction 60 1172-1182.

Gupta C, Siegel S \& Ellis D 1991 The role of EGF in testosteroneinduced reproductive tract differentiation. Developmental Biology 146 106-116.

Herbst AL \& Bern HA 1981 Developmental Effects of Diethylstilbestrol (DES) in Pregnancy. New York: Thieme-Stratton Inc.

Herbst AL, Ulfelder H \& Poskanzer DC 1971 Adenocarcinoma of the vagina. Association of maternal stilbestrol therapy with tumor appearance in young women. New England Journal of Medicine 284 878-881.

Hiroi $\mathrm{H}$, Inoue $\mathrm{S}$, Watanabe $\mathrm{T}$, Goto $\mathrm{W}$, Orimo A, Momoeda $\mathrm{M}$, Tsutsumi O, Taketani Y \& Muramatsu M 1999 Differential immunolocalization of estrogen receptor $\alpha$ and $\beta$ in rat ovary and uterus. Journal of Molecular Endocrinology 22 37-44. 
Hom YK, Young P, Wiesen JF, Miettinen PJ, Derynck R, Werb Z \& Cunha GR 1998 Uterine and vaginal organ growth requires epidermal growth factor receptor signaling from strom. Endocrinology 139 913-921.

Ignar-Trowbridge DM, Nelson KG, Bidwell MC, Curtis SW, Washburn TF, McLachlan JA \& Korach KS 1992 Coupling of dual signaling pathways: epidermal growth factor action involves the estrogen receptor. PNAS 89 4658-4662.

Iguchi T, Uchima FDA \& Bern HA 1987 Growth of mouse vaginal epithelial cells in culture: effect of sera and supplemented serum-free media. In Vitro Cellular and Developmental Biology 23 535-540.

Iguchi T, Edery M, Tsai PS, Ozawa S, Sato T \& Bern HA 1993 Epidermal growth factor receptor levels in reproductive organs of female mice exposed neonatally to diethylstilbestrol. Proceedings of the Society for Experimental Biology and Medicine 204 110-116.

Jefferson WN, Couse JF, Banks EP, Korach KS \& Newbold RR 2000 Expression of estrogen receptor $\beta$ is developmentally regulated in reproductive tissues of male and female mice. Biology of Reproduction $62310-317$.

Josso N \& Picard JY 1986 Anti-Müllerian hormone. Physiological Reviews 66 1038-1090.

Kamiya K, Sato T, Nishimura N, Goto Y, Kano K \& Iguchi T 1996 Expression of estrogen receptor and proto-oncogene messenger ribonucleic acids in reproductive tracts of neonatally diethylstilbestrolexposed female mice with or without postpubertal estrogen administration. Experimental and Clinical Endocrinology and Diabetes 104 111-122.

Kanno Y, Koike S \& Noumura T 1994 Immunohistochemical localization of epidermal growth factor in the developing rat gonads. Zoological Science 11 83-87.

Kapur S, Tamada H, Dey SK \& Andrews GK 1992 Expression of insulin-like growth factor-I (IGF-I) and its receptor in the peri-implantation mouse uterus, and cell-specific regulation of IGF-I gene expression by estradiol and progesterone. Biology of Reproduction 46 208-219.

Koike S \& Noumura T 1993 Immunohistochemical localizations of TGF- $\beta$ in the developing rat gonads. Zoological Science 10 671-677.

Koike S, Sakai M \& Muramatsu M 1987 Molecular cloning and characterization of rat estrogen receptor cDNA. Nucleic Acids Research 15 2499-2513.

Krege JH, Hodgin JB, Couse JF, Enmark E, Warner M, Mahler JF, Sar M, Korach KS, Gustafsson JA \& Smithies O 1998 Generation and reproductive phenotypes of mice lacking estrogen receptor $\beta$. PNAS 95 15677-15682.

Kuiper GGJM, Enmark E, Pelto-Huikko M, Nilsson S \& Gustafsson JA 1996 Cloning of a novel estrogen receptor expressed in rat prostate and ovary. PNAS 93 5925-5930.

Kuiper GGJM, Carlsson B, Grandien K, Enmark E, Häggblad J, Nilsson S \& Gustafsson JA 1997 Comparison of the ligand binding specificity and transcript tissue distribution of estrogen receptors $\alpha$ and $\beta$. Endocrinology 138 863-870.

Lemmen JG, Broekhof JLM, Kuiper GGJM, Gustafsson JÅ, Van der Saag PT \& Van der Burg B 1999 Expression of estrogen receptor alpha and beta during mouse embryogenesis. Mechanisms of Development 81 163-167.

Li S 1994 Relationship between cellular DNA synthesis, PCNA expression and sex steroid hormone receptor status in the developing mouse ovary, uterus and oviduct. Histochemistry 102 405-413.

Lubahn DB, Moyer JS, Golding TS, Couse JF, Korach KS \& Smithies O 1993 Alteration of reproductive function but not prenatal sexual development after insertional disruption of the mouse estrogen receptor gene. PNAS 90 11162-11166.

Ma L, Benson GV, Lim H, Dey SK \& Maas RL 1998 Abdominal B $(A b d B)$ Hoxa genes: regulation in adult uterus by estrogen and progesterone and regression in Müllerian duct by the synthetic estrogen diethylstilbestrol (DES). Developmental Biology 197 141-154.

Maruyama K, Endoh H, Sasaki-Iwaoka H, Kanou H, Shimaya E, Hashimoto S, Kato S \& Kawashima H 1998 A novel isoform of rat estrogen receptor beta with 18 amino acid insertion in the ligand binding domain as a putative dominant negative regulator of estrogen action. Biochemical and Biophysical Research Communications 246 142-147.

McCormack SA \& Glasser SR 1980 Differential response of individual uterine cell types from immature rats treated with estradiol. Endocrinology 106 1634-1648.

McLachlan JA, Newbold RR \& Bullock BC 1980 Long-term effects on the female mouse genital tract associated with prenatal exposure to diethylstilbestrol. Cancer Research 40 3988-3999.

Murphy LJ, Murphy LC \& Friesen HG 1987 Estrogen induces insulin-like growth factor-I expression in the rat uterus. Molecular Endocrinology 1 445-450.

Nelson KG, Takahashi T, Bossert NL, Walmer DK \& McLachlan JA 1991 Epidermal growth factor replaces estrogen in the stimulation of female genital-tract growth and differentiation. PNAS 88 21-25.

Nelson KG, Takahashi T, Lee DC, Luetteke NC, Bossert NL, Ross K, Eitzman BE \& McLachlan JA 1992 Transforming growth factor- $\alpha$ is a potential mediator of estrogen action in the mouse uterus. Endocrinology 131 1657-1664.

Newbold RR, Bullock BC \& McLachlan JA 1983a Exposure to diethylstilbestrol during pregnancy permanently alters the ovary and oviduct. Biology of Reproduction 28 735-744.

Newbold RR, Tyrey S, Haney AF \& McLachlan JA $1983 b$ Developmentally arrested oviduct: a structural and functional defect in mice following prenatal exposure to diethylstilbestrol. Teratology 27 417-426.

Newbold RR, Carter DB, Harris SE \& McLachlan JA 1984 Molecular differentiation of the mouse genital tract: altered protein synthesis following prenatal exposure to diethylstilbestrol. Biology of Reproduction 30 459-470.

Nielsen M, Björnsdóttir S, Høyer PE \& Byskov AG 2000 Ontogeny of oestrogen receptor $\alpha$ in gonads and sex ducts of fetal and newborn mice. Journal of Reproduction and Fertility 118 195-204.

Ozawa S, Iguchi T, Sawada K, Ohta Y, Takasugi N \& Bern HA 1991 Postnatal vaginal nodules induced by prenatal diethylstilbestrol treatment correlate with later development of ovary-independent vaginal and uterine changes in mice. Cancer Letters 58 167-175.

Pelletier G, Labrie C \& Labrie F 2000 Localization of oestrogen receptor $\alpha$, oestrogen receptor $\beta$ and androgen receptors in the rat reproductive organs. Journal of Endocrinology 165 359-370.

Petersen DN, Tkalcevic GT, Koza-Taylor PH, Turi TG \& Brown TA 1998 Identification of estrogen receptor $\beta_{2}$, a functional variant of estrogen receptor $\beta$ expressed in normal rat tissues. Endocrinology 139 1082-1092.

Poulsen SS, Nexø E, Olsen PS, Hess J \& Kirkegaard P 1986 Immunohistochemical localization of epidermal growth factor in rat and man. Histochemistry 85 389-394.

Quarmby VE \& Korach KS 1984 The influence of $17 \beta$-estradiol on patterns of cell division in the uterus. Endocrinology 114 694-702.

Raynaud JP 1973 Influence of rat estradiol binding plasma protein (EBP) on uterotrophic activity. Steroids 21 249-258.

Raynaud JP, Mercier-Bodard C \& Baulieu EE 1971 Rat estradiol binding plasma protein (EBP). Steroids 18 767-788.

Rothschild TC, Calhoon RE \& Boylan ES 1987/88 Genital tract abnormalities in female rats exposed to diethylstilbestrol in utero. Reproductive Toxicology 1 193-202.

Sahlin L, Norstedt G \& Eriksson H 1994 Estrogen regulation of the estrogen receptor and insulin-like growth factor-I in the rat uterus: a potential coupling between effects of estrogen and IGF-I. Steroids 59 421-430. 
Sato T, Chiba A, Hayashi S, Okamura H, Ohta Y, Takasugi N \& Iguchi T 1994 Induction of estrogen receptor and cell division in genital tracts of male mice by neonatal exposure to diethylstilbestrol. Reproductive Toxicology 8 145-153.

Sato T, Ohta Y, Okamura H, Hayashi S \& Iguchi T 1996 Estrogen receptor (ER) and its messenger ribonucleic acid expression in the genital tract of female mice exposed neonatally to tamoxifen and diethylstilbestrol. Anatomical Record 244 374-385.

Satokata I, Benson G \& Maas R 1995 Sexually dimorphic sterility phenotypes in Hoxa 10-deficient mice. Nature 374 460-463.

Shiraga M, Takahashi S, Miyake T, Takeuchi S \& Fukamachi H 1997 Insulin-like growth factor-I stimulates proliferation of mouse uterine epithelial cells in primary culture. Proceedings of the Society for Experimental Biology and Medicine 215 412-417.

Shiraga M, Komatsu N, Teshigawara K, Okada A, Takeuchi S, Fukamachi H \& Takahashi S 2000 Epidermal growth factor stimulates proliferation of mouse uterine epithelial cells in primary culture. Zoological Science 17 661-666.

Taylor HS, Vanden Heuvel GB \& Igarashi P 1997 A conserved Hox axis in the mouse and human female reproductive system: late establishment and persistent adult expression of the Hoxa cluster genes. Biology of Reproduction 57 1338-1345.
Tomooka Y, DiAugustine RP \& McLachlan JA 1986 Proliferation of mouse uterine epithelial cells in vitro. Endocrinology 118 1011-1018.

Visser JA, McLuskey A, Verhoef-Post M, Kramer P, Grootegoed JA \& Themmen APN 1998 Effect of prenatal exposure to diethylstilbestrol on Müllerian duct development in fetal male mice. Endocrinology 139 4244-4251.

Warot X, Fromental-Ramain C, Fraulob V, Chambon P \& Dollé P 1997 Gene dosage-dependent effects of the Hoxa-13 and Hoxd-13 mutations on morphogenesis of the terminal parts of the digestive and urogenital tracts. Development 124 4781-4791.

Zhang Z, Funk C, Roy D, Glasser S \& Mulholland J 1994 Heparinbinding epidermal growth factor-like growth factor is differentially regulated by progesterone and estradiol in rat uterine epithelial and stromal cells. Endocrinology 134 1089-1094.

Zhang Z, Laping J, Glasser S, Day P \& Mulholland J 1998 Mediators of estradiol-stimulated mitosis in the rat uterine luminal epithelium. Endocrinology 139 961-966.

Received 14 May 2001

Accepted 30 May 2001 